\title{
Stimulating Strategy Children Experiencing Late Language Emergence (LLE) During Pandemic Covid-19
}

\author{
Evania Yafie $^{1,2, *}$ Ilaria Giavarini ${ }^{3}$ Lisa Nur Maulidia $^{1}$ \\ ${ }^{1}$ Early Childhood Education, Universitas Negeri Malang, Malang, Indonesia \\ ${ }^{2}$ Educational Technology, Universiti Teknologi Malaysia, Johor Bahru, Malaysia \\ ${ }^{3}$ Faculty of Medicine, Speech and Language Therapy, University of Milan, Milan, Italy \\ *Corresponding author. Email: evania.yafie.fip@um.ac.id
}

\begin{abstract}
Language development for children is significant to communicate and express themselves with the outside environment. Late Language Emergency (LLE) will be an obstacle for aspects of language development and can affect other factors. The purpose of this study was to determine the appropriate and effective strategy in stimulating language delay according to the character and needs of the child. The method used in this research is literature analysis or literature study. From the results of this study, we can find out a strategy to stimulate late language emergency, namely by looking at the stage of development of children according to their age by paying attention: (1) physical growth from language readiness, (2) familiarity with children's communication languages, (3) inviting children to communicate at any time with correct words and sentences, (4) giving positive appreciation, (5) using media or technology in stimulating, and (6) consult with linguists.
\end{abstract}

Keywords: Strategy, Speak Delay, Early Childhood, Covid 19

\section{INTRODUCTION}

Language development for early childhood is an essential aspect of supporting their lives. Language relates to how a person can interact and communicate with other people. Through language, a child can convey his ideas and opinions. However, if this has problems, it will undoubtedly affect other aspects. In the brain, the speech process is very complicated. They are starting from the process of listening, recording words, understanding the meaning of words, saying, using the right choice of words in the social situation experienced.

According to Montessori, children aged 3-6 years are in a sensitive period or sensitive period, in this period certain functions in children need to be stimulated and directed so as not to experience obstacles in their development (Hurlock, 1978). If during this sensitive period, the stimulation provided is not optimal, it is feared that the child will experience problems in his development, in the speaking aspect, for example. This whole process is the leading work task for the brain. On the left side of the brain, there is a location for the speech centre, as for imagination, appreciation when talking located on the right side of the brain. These two parts must be balanced so that the child can speak well. If good brain development is only part left alone, there will be a shortage in the narrative process Language (Syaodih, 1995).

Adults should be able to recognize various delays in aspects of child development, especially parts of the language. Late language emergence (LLE) is a delay in language onset without diagnosed symptoms of other disabilities or developmental delays in different domains such as cognitive, motoric, social and others (Asha, 2020). Delays may occur due to the lack of stimulation of the person to be around children. Mulyati (2013) mentions a child is said to be too late to talk when he could not reach the stage of language units in the form of sounds, words and sentences according to age. Hurlock (1978) explains that the speech delay occurred when a child's speech development level was below the level of speech development of children in general, which can be determined by the precision of word usage and can affect the child's social relationships such as the development of the play.

At this time, due to the impact of a pandemic, which causes children to learn in the home, it can also lead to reduced interaction between children and the outside world. Language delays in children may occur due to the 
lack of stimulation from adults around the children due to parenting patterns and parents' busyness. In some areas and based on the results of a survey via google form that we conducted in our region, parents commented that their child, who is in the 3-4-year age range, still has problems expressing what he wants. They can understand commands, but it is difficult to convey what to expect. However, when interacting with peers, they occasionally argue out loud. Given the real-world situation, it is very important to be aware of what are the risks and protective factors for late language emergency (LLE).

The causes of LLE in healthy children are unknown. However, several variables are thought to play a role. The American Speech and Language Association (ASHA) advises considering risk and protective factors. Children are late in speaking because they experience interference at the time of delivery, not during the process of receiving language from outside themselves. As a result of delays in speech cause the child difficult to socialize and make adjustments to the surrounding environment (Khoiriyah, 2015). There are several types of speech delays as mentioned by Van Tiel (Tsuraya, 2013) including: (1) specific language impairment; (2) speech and language expressive disorder; (3) centrum auditory processing disorder; (4) pure dysphatic development; (5) gifted visual-spatial learner; and (6) disynchronous developmental. Based on these types, it can be seen that the cause of children experiencing delays is not only from child development but also can come from internal development such as neurological disorders and intelligence.

The factors that have the potential to be a risk to children should be considered more by parents and teachers. Factors such as family condition and child's condition include gender. Compared to girls, boys are at higher risk for LLE (Horowitz et al., 2003; Klee et al., 1998; Rescorla, 1989; Rescorla \& Achenbach, 2002; Rescorla \& Alley, 2001); children who had motor development impediments were mostly found to have speech impediments (Klee et al., 1998; Rescorla \& Alley, 2001); The conditions at which the children are born also affect. That is, children, who were born less than $85 \%$ of their optimal birth weight or had an earlier birth at 37 weeks' gestation were also found to have a higher risk for LLE (Zubrick et al., 2007). These things must be understood by parents in detecting problems in children's language development from the early history of the birth and their background. According Mangunsong (Tsuraya, 2013) there is a risk of delays in speech, such as: (1) affecting conceptual abilities and accomplishments education of children; and (2) impact factor of social and personal, unfamiliarity others to talks conducted by the child will cause the child to feel low self-esteem.

The purpose of this study was to determine the appropriate and effective strategy in stimulating language delay according to the character and needs of the child. The author will describe the description and steps of the strategies used in stimulating child development according to the child's age stage.

\section{METHOD}

In this research, we used to study the literature. In the literature, the author uses reinforcement on several references to obtain the answer to the problems discussed. According to Zed (2014), in the research literature, it is not only the first step to compiling a research framework but also at the same time utilizing library resources to obtain research data. Literary studies can be examined from various sources, both books, journals, and other academic articles.

\section{RESULT AND DISCUSSION}

\subsection{Early Childhood Language Development}

Child development is the most fundamental thing, especially during the COVID 19 pandemic. Parents must provide stimulus data to optimize all aspects of child development, especially parts of children's language. At the age of five years, children have great potential for optimizing aspects of their product, including language and speaking skills (Hurlock, 2002). Sonawat and Jasmine Maria Francis (Usman, 2015) state that there are five functions of language. First, language becomes a tool to express desires. Second, language can be used to express emotions. Third, language is a tool for obtaining information. Fourth, language is a tool for social relationships. Fifth, language is a tool for personal identification. Based on these five functions, language is used as a tool to express what children want to others. Such as when children feel emotions, children want to exchange information and receive information, where this increases the intensity of children's social relationships with the outside world to help children make personal identification of themselves. When children carry out social interactions, they need essential capital in the form of language and speaking skills, where these skills must be learned first and not necessarily owned by children (Zusfindhana, 2018).

Also, there are four aspects of language according to Bromley (Dhieni, 2013), namely: (1) listening; (2) speaking; (3) reading; and (4) writing. Suppose they get the right stimulation according to their development stages. According to Dhieni (2008), there are aspects related to children's speech development, including vocabulary, syntax (grammar), semantics and phonemes. Jalongo (2007) suggests four elements, namely pragmatic, semantic, syntactic and graphic aspects. The practical part, according to Rahardi (2006), is the mastery of the language social interaction system, the functional element contains how to use language concerning the context of its use. The meaning of the language can be understood if the context is known. Pragmatic boundaries are the rules for the benefit of language regarding forms 
and intentions associated with the speaker's intent, context, and circumstances.

According to Hurlock (1978) speaking is another form of language that uses articulation to convey meaning and is the most effective form of communication, widely used and important to do. Talking has a function to establish communication with other people. If children are able to master words, sentences and grammar, then they can also communicate well and more effectively (Syaodih, 1995). Children will find it easier to express what he feels, what he wants when speaking skills are well developed. In addition, there is a link between the form and function of speech. If children have mastered words, sentences and grammar, then they will also be able to communicate well and more effectively (Syaodih, 1995).

Children will be more confident and happier when what they say is understood by the people around them. Widyorini and Tiel (2017) explain the aspects when children talk. These aspects are phonological aspects, graphical aspects, semantic aspects (language/reading comprehension) and pragmatic aspects (language use). The pragmatic aspect (use of language), in this case, the child is able to use language in the right context and what it is used for. Wiyani (2014) also explains in her book that there are four aspects in speaking, namely phonology, semantics, syntax and pragmatic. The pragmatic aspect is the principle of how language is used in different social situations. There are five aspects or systems of language rules, namely phonology, morphology, syntax, semantics and pragmatics, and this was expressed by Santrock (2007).

\subsection{Factors and Risk of Late Language Emergency}

During the COVID 19 pandemic, the condition of children at home was greatly influenced by the adults around them. Therefore, an important role is currently held by parents. The situation in the family dramatically determines the development of the child. In early language development, namely, the age of 12 months is an accurate determinant of children's speaking skills at the age of 2 years (Reilly et al., 2007). Family history also affects a child's LLE. Families who have experienced LLE are likely to pass on to the children who are the successors of the family. (Ellis Weismer, MurrayBranch, \& Miller, 1994; Rescorla \& Schwartz, 1990).

The existence of siblings can also be said to be the influence of children experiencing speech delays. Children with siblings will share care with their mother, and this may reduce the stimulation the child should get. That's why single children rarely get LLE disorders (Zubrick et al., 2007). The high risk of LLE can also make by the lack of education of the mother or family (see Zubrick et al., 2007); Education of mothers and families is also considered an essential factor to prevent children from the possibility of LLE. Children will experience a sensitive period at pre-school age; at this time, the child begins to be sensitive when given stimulation to develop their potential. Therefore, children need conditions and stimuli in accordance with their needs. This is intended so that the growth and development of children can be optimal, including those related to the function of language and speech development (Zusfindhana, 2018).

\subsection{Strategies to Stimulate for Late Language Emergency in Pandemic Covid 19}

Optimal children's language development will help development in other aspects because children can express their ideas for social interaction and develop their thoughts when they are outside. Santrock (2002) divides language development into five stages: (1) The first stage relates to reflex voicing where all activities of infants aged 0-3 weeks are still reflex, unconscious, unwilling, do not ask or demand something, and do not respond to stimuli such as cry and voice. At this time, the parents should give encouragement to embrace affection and let the child freely move all members of the body in expressing motion. After four weeks, a voice and a different cry could be heard.

Children begin to communicate with different types of crying, so parents should understand the child's crying style and communication symbols. However, this does not mean that the baby can distinguish every stimulus and is still a reflex; (2) The second stage relates to the identification and early intervention that can reduce the impact of risk factors (Guralnick, 1984; National Research Council, 2001; Thelin \& Fussner, 2005). The American Joint Committee on Learning Disabilities (NJCLD; 2007) giving statement there are several protective factors for children that are suggested to avoid them from risks such as exposing a richer and more diverse vocabulary, learning to speak related to syntax, and discourse patterns; the existence of a learning environment that is responsive and sensitive to cultural and linguistic backgrounds; providing access to printed materials; the presence of involvement in structured and unstructured individual/group game interactions and conversations; involvement in gross and fine motor activities; as well as support for access to good communication and services. Santrock (2009) in his book states that language progress that occurs in early childhood will provide a foundation for further child development at primary school age.

Children have different language ability characteristics at each age. According to Jamaris (Susanto, 2011), there are four characteristics of language skills in children aged four years. First, there is rapid development in children's language development as they are able to use sentences correctly and correctly. Second, they have mastered 90 per cent of the phonemes and syntax of the language. Third, children can respond to 
conversations with other people. At the age of 4-5 years, the children are able to interact with the people around them and have close conversations.

Babbling is experienced when the baby is 6-7 weeks old. At this time, the baby will repeat the sound it hears. The baby begins to produce various sounds and begins to make consonants like $\mathrm{p}, \mathrm{b}, \mathrm{g}$ and nasal consonants (nasal) like $\mathrm{n}$. these sounds are often combined with vowels such as "pa pa pa pa, ba ba ba, and en en en". At this stage, parents should provide stimulation by inviting children to talk repeatedly and show expressions according to the emotions the child responds to; (3) The third stage, the Lalling stage which can be called babbling, usually starts when the baby is 6-8 months old. The stage is almost similar to the babbling stage; the only difference lies in the form of the babbling. At this stage, parents invite to speak incorrect sentences so that children can imitate slowly. If the child still mentions the wrong parents, they can give the correct word so that the child gets used to imitating the correct one. Parents should imitate the wrong word of the child; (4) The fourth stage, namely the Ecolalia stage which occurs at the age of 9-10 months, the child is able to imitate the words or words of others without changing them. This effort is also accompanied by gestures and hand movements. The repetition that is done by the child is not accompanied by meaning. At this stage, parents should stimulate children by asking questions and telling stories, and then the child repeats the story in more complex language; (5) The fifth stage, namely the True Speech stage, this stage is the stage of the last language development. This stage is often referred to as the first word or the first-word stage, usually occurs when the child is $9-10$ months old. At this stage, the parents provide stimulus with more complex sentences and language with a variety of vocabulary. Provide children with a variety of stories.

In order to understand emotional development in children, Greenspan (Zusfindhana, 2018) mentions that there are six stages of emotional development that children must go through. The stages of emotional development include: (1) The first stage, at this stage stimuli from the environment can be accepted and processed by the child; (2) The second stage: This stage deals with intimacy and intimacy. The intimacy that parents develop with their babies plays an important role. This intimacy relates to love, warmth, and joy when it comes to relationships with other people. The stimulation given at this stage will strengthen language, cognitive and movement skills which will have an impact on the capacity to move, think and speak in the future; (3) The third stage: This stage brings the children to two-way communication skills. This form of communication is not only verbal but can be a response or gesture. Two-way communication can generate initiative and allow children to determine their own emotions so that they can show emotions by hugging, holding or smiling when spoken to; (4) The fourth stage: at this stage, there is complex communication. Children begin to include desires when they act. They no longer just follow their parents' orders and begin to show assertive curiosity, show facial expressions, and show vocalizations; (5) The fifth stage: this stage deals with emotional ideas. At this stage, the child is able to think of ideas and recognize symbols. Children are also able to mix language that engages emotions. This ability to create ideas initially develops in pretend play, which provides ample opportunity to experiment with feelings, desires and hopes; (6) The sixth stage: at this stage, the child is able to think emotionally. Children can arrange parts by piece in a logical order, and according to reality, express emotions in play, can predict their own feelings and understand that their behaviour and feelings also have an impact on others.

As a result of language development disorders, usually have psychosocial effects on children, such as cognitive abilities, as well as limited socialization or emotion. Therefore, parents and educators need to detect the development and language and speaking skills of children from 1 month to 6 years of age. Handling of disturbances can be done with help from the environment around the child, especially family. The role of the environment can stimulate children, let children express themselves, give freedom to children to tell stories about their experiences and provide answers that are good and understandable to children (Syaodih, 1995).

Some strategies that teachers can do with children who experience speech delays: (1) Invite children to speak correctly, slowly and repeatedly. This is supported by the theory of Santrock (2009) which states that providing support inside or outside of school is the key; (2) Paying attention to the grammar used. This is consistent with the theory of Roger Brown (Santrock, 2009) which states that parents can provide support by encouraging children to speak grammatically; (3) Involving children in every conversation and correcting if any of their pronunciation is wrong. This is following Santrock (2009) statement that children will be helped if their parents and teachers actively involve them in a conversation; (4) Using technology media to support vocabulary in children. This is supported by Miller's theory (Santrock, 2009) that there are three ways to help children's speech using three types of technology, namely: computers, audiobooks, and educational television; and (5) Conducting consultations with doctors and psychologists to determine the child's development.

\section{CONCLUSION}

Learning at home during the COVID 19 pandemic requires hard work from people in the environment around the child. The strategy to stimulate late language emergency is to look at the child's developmental stage according to their age by paying attention to: (1) physical growth from readiness to make mouth movements, (2) crying language as communication, (3) inviting children to communicate at any time with correct words and 
sentences, (4) Give positive appreciation at each stage of their growth, (5) Use a variety of media and technology to stimulate language development, and (6) consult with linguists so that delays do not occur or have other impacts. The importance of this stimulus strategy, of course, requires the determination of parents, especially during the COVID 19 pandemic.

\section{REFERENCES}

[1] Dhieni, N. 2013. Metode Pengembangan Bahasa. Tanggerang Selatan: Universitas Terbuka.

[2] Ellis-Weismer, S., Murray-Branch, J., \& Miller, J. F. 1994. A prospective longitudinal study of language development in late talkers. Journal of Speech, Language, and Hearing Research, 37(4), 852-867.

[3] Guralnik, D. B. 1984. Webster New World Dictionary of the American Language. New York: Warner Books.

[4] Hoff-Ginsberg, E. 1994. Influences of mother and child on maternal talkativeness. Discourse Processes, 18, 105-117.

[5] Horowitz, S. M., Irwin, J. R., Briggs-Gowan, M. J., Bosson Heenana, J. M., Medoza, J., \& Carter, A. S. 2003. Language delay in a community cohort of young children. Journal of the American Academy of Child and Adolescent Psychiatry, 42, 932-940.

[6] Hurlock, E. B. 1978. Perkembangan Anak. Jakarta: Penerbit Erlangga.

[7] Hurlock, E. B. 2002. Psikologi Perkembangan. Jakarta: Erlanga.

[8] Jalongo, M. R. 2007. Early Childhood language Arts. USA: Pearson Education, Inc.

[9] Khoiriyah. 2015. Model Pengembangan Kecakapan Berbahasa Anak yang Terlambat Berbicara (Speech Delay). Aceh: Universitas Syiah Kuala Darussalam.

[10] Klee, T., Carson, D. K., Gavin, W. J., Hall, L., Kent, A., \& Reece, S. 1998. Concurrent and predictive validity of an early language screening program. Journal of Speech, Language, and Hearing Research, 41, 627-641.

[11] Mulyati, S. 2013. Perkembangan Psikologi Anak. Yogyakarta: Laras Media Prima.

[12] National Joint Committee on Learning Disabilities. 2007. Learning disabilities and young children: Identification and intervention [Technical report]. Retrieved October, 2, 2020, from www.asha.org/policy.

[13] National Research Council. 2001. Nutrient Requirement of Dairy Cattle. 8th Revised Edition. National Academy Press, Washington

[14] Nurbiana, D. 2008. Metode pengembangan bahasa. Jakarta: Pusat Penerbitan Universitas Terbuka.

[15] Rahardi, K. 2006. Pragmatik: Kesantunan Imperatif Bahasa Indonesia. Jakarta: Erlangga.
[16] Reilly, S., Wake, M., Bavin, E. L., Prior, M., Williams, J., Bretherton, L., Eadie, P., Barrett, Y., \& Ukoumunne, O. C. 2007. Predicting language at 2 years of age: A prospective community study. Pediatrics, 120(6), 1441-1449.

[17] Rescorla, L. A. (1989). The Language Development Survey: A screening tool for delayed language in toddlers. Journal of Speech and Hearing Disorders, 54, 587-599.

[18] Rescorla, L. A., \& Achenbach, T. M. 2002. Use of the Language Development Survey (LDS) in a national probability sample of children 18 to 35 months old. Journal of Speech, Language, and Hearing Research, 45(4), 733-743.

[19] Rescorla, L. A., \& Alley, A. 2001. Validation of the Language Development Survey (LDS): A parent report tool for identifying language delay in toddlers. Journal of Speech, Language, and Hearing Research, 44, 434-445.

[20] Rescorla, L. A., \& Schwartz, E. 1990. Outcome of toddlers with specific expressive language delay. Applied Psycholinguistics, 11, 393-407.

[21] Santrock W. J. 2009. Psikologi Pendidikan. Jakarta: Salemba Humanika.

[22] Santrock, J. W. 2002. Life-Span Develoment, Perkembangan Masa Hidup. Jakarta: Erlangga.

[23] Santrock, J. W. 2007. Perkembangan Anak. Jakarta: Erlangga.

[24] Susanto, A. 2011. Perkembangan Anak Usia Dini. Jakarta: Kencana.

[25] Syaodih, E. 1995. Psikologi Perkembangan. Bandung: Mandar Maju.

[26] Thelin, J. W., \& Fussner, J.C. 2005. Factors Related to the Development of Communication in CHARGE Syndrome. Tennessee: University of Tennessee.

[27] Usman, M. 2015. Perkembangan Bahasa Dalam Bermain dan Permainan. Yogyakarta: Deepublish.

[28] Wells, G. 1985. Language development in the preschool years: Language at home and at school. Cambridge. UK: Cambridge University Press.

[29] Widyorini, E., \& Tiel, J. M. V. 2017. Disleksia Deteksi, Diagnosis, Penanganan di Sekolah \& Rumah Edisi Pertama. Jakarta: Prenada.

[30] Wiyani, N. A. 2014. Psikologi Perkembangan Anak Usia Dini. Yogyakarta: Gava Media.

[31] Zed, M. 2014. Metode Penelitian Kepustakaan. Jakarta: Yayasan Obor Indonesia.

[32] Zubrick, S. R., Taylor, C. L., Rice, M. L., \& Slegers, D. W. 2007. Late language emergence at 24 months: An epidemiological study of prevalence, predictors, and covariates. Journal of Speech, Language, and Hearing Research, 50(6), 1562 1592.

[33] Zusfindhana, I. H. 2018. Implementasi Pendekatan Floor Time untuk Mengatasi Anak Lambat Bicara Usia 3-4 Tahun. Jember: IKIP PGRI Jember. 